\title{
Overview of Women Entrepreneurs in South Africa
}

\author{
Fortunate Mandipaka \\ Teaching and Learning Centre University of Fort Hare \\ E-mail:fmandie@gmail.com
}

\section{Doi:10.5901/mjss.2014.v5n9p127}

\begin{abstract}
This paper provides an overview of women entrepreneurs in South Africa. The paper also investigates the contribution and significance of women entrepreneurs to the South African economy. Government support strategies offered to women entrepreneurs are also discussed. Literature review from various sources was used to gather data.
\end{abstract}

Keywords: Contribution; Women Entrepreneurs; Support Strategies; South Africa

\section{Introduction}

The South African economy has been experiencing low economic growth, high unemployment and an unsatisfactory level of poverty for the past years. Most of the women and young people in South Africa with the unemployment rate currently being 25.7 per cent (South African Chamber of Commerce and Industry, 2013). Due to these factors more people are forced to choose entrepreneurship as their career path or forced to be self-employed (Nieman \& Nieuwenhuizen, 2003). This review paper endeavours to discuss the contributions and significance of women entrepreneurs to the economy of South Africa as well as the support strategies offered to the women entrepreneurs by the Government.

\section{Overview of Women Entrepreneurs in South Africa}

Over the last twelve years, women in South Africa have been more active in government and policy-making, with $43 \%$ of the national cabinet and $37 \%$ of our parliamentarians being female. Women have also progressively begun to extend their benefit in the economic sphere by successively managing SMMEs. The Labour Force Survey for 2005 reveals that women represent $52 \%$ of the South African population and black women are in fact the largest single self-employed segment of the population (International Finance Corporation, 2006).

South African women entrepreneurs engage in survivalist activities such as sewing co-operatives, chicken farming, candle-making, gardening, and arts and crafts. All these activities that women entrepreneurs engage in are commonly referred to as micro-enterprise projects. They are initiated jointly by women's community groups which reflect women's homemaking skills in combination with other domestic or income-generating activities. Research reveals that private and public sector support for these activities are lacking, exposing women to high risks and poor outcomes (Kassim \& Hendriks, 2002). Most women entrepreneurs in South Africa play a major role in the social and economic well-being of their communities. The Government has recognised the value of their contribution to their communities by giving them support and promoting a change in their attitudes towards the meaning of work (Women in Africa Doing Business, 2008).

In South Africa gender inequality is a big problem. South African women are still having problems being able to have equal rights and advantages as South African men. Most of the women entrepreneurs in South Africa have been excluded from access to credit, ownership of land, educational opportunities and skills development (Department of Trade and Industry, 2006).

Most South African women entrepreneurs contribute much to the rural economy. Though women may be entrepreneurs in their own rural homes, it is hard for them to branch out and have an actual building from which to run a business. This is so because they have problems getting finance to possibly open their own business. Women entrepreneurs are mostly found doing jobs such as catering, fashion designing, cooking and being wedding coordinators (White, Jones, Riley \& Fernandez, 2009). 


\section{The Contributions Made By SMMEs Owned by Women Entrepreneurs to the Economy of South Africa}

Small businesses and entrepreneurship play an important role in stimulating economic activity, creating jobs, alleviating poverty and uplifting living standards (Van Vuuren \& Groenewald, 2007). Women entrepreneurs in South Africa play a part towards the economic development, but their contribution has not been sufficiently nurtured and developed.

South Africa is a developing country which is faced with high levels of unemployment, low levels of formal and higher education and also faced with the migration of individuals from rural areas to cities. The country thus has a critical need for entrepreneurs in the small, micro- and medium enterprises (SMMEs) who could assist in fighting unemployment and crime and help stimulate economic growth (Maas \& Herrington, 2006).

The establishment of small businesses by women entrepreneurs provide economic stability and a better distribution of economic activities (Nieuwenhuizen, 2003). The women of South Africa contribute to the South African economy in many ways. Women entrepreneurs are suppliers of employment and creators of work opportunities, innovators and initiators. According to Thurik and Wennekers, (2001) small businesses are both a means of entrepreneurship and a source of employment and income. The SMMEs owned by women entrepreneurs play an significant role in the South African economy by improving welfare, alleviating poverty, and also is a source of wealth and employment creation.

Women entrepreneurs play a crucial role in people's efforts to meet basic needs and help disadvantaged groups, disabled people and rural families. Job creation increases as each small business organisation is striving towards helping disadvantaged groups, in that way achieving credibility in the tendering processes and complying with Black Economic Empowerment (BEE) policies, as well as, contributing significantly towards alleviating poverty (Ntsika Enterprise Promotion Agency,2000) .

\section{Support Strategies for Women Entrepreneurs in South Africa}

The President of South Africa in his speech at the women's day celebration in August 2011 emphasized that there is low participation of women in business. He noted that this is due to, amongst others, poor access to business opportunities and information, financial markets as well as knowledge of how to run businesses. Thus a number of support programmes across government departments, were designed to assist women to curb the challenges they face. One of these is the promotion of cooperatives especially in rural areas to enable women to participate in the economy. The Department of Trade and Industry supports women cooperatives by fast tracking their registration as well as providing funding for capital equipment under the cooperative Incentive Scheme (South African Government Information; 2011)

\subsection{Various support strategies offered by Department of Trade and Industry}

The South African Government is well aware that South African women entrepreneurs face many obstacles when it comes to starting, growing and sustaining enterprises. For this reason, the Department of Trade and Industry (DTI) is working actively to encourage more South African women entrepreneurs to start and run their own productive businesses (Africa Awards for Entrepreneurship, 2011).

\subsubsection{South African Women Entrepreneur's Network (SAWEN)}

The South African Women Entrepreneurs' Network (Sawen) represents and supports women entrepreneurs within the South African small, medium and micro enterprise (SMME) sector. SAWEN was established by the Department of Trade and Industry (DTI) in response to the fact that women entrepreneurs in South Africa continuously face an enormous number of obstacles in starting, growing and sustaining their own enterprises (South Africa Info, 2004). Thus it seeks to minimise the obstacles, African women entrepreneurs face.

According to South Africa Info (2004) SAWEN is an organisation that strives to bring the country's women entrepreneurs together and addressing the challenges associated with business failure. The network also facilitates access to valuable business resources, as well as information and opportunities for South African women entrepreneurs, so that they can take part in the global economy (Africa Awards for Entrepreneurship, 2011). SAWEN identifies its clients as being any female South African citizen owning or managing an enterprise, thus contributing towards developing the South African economy, as well as any female person who has aspirations to start her own enterprise. The organisation currently charges an annual membership fee of R250. 


\subsubsection{Technology for Women in Business (TWIB)}

Technology for Women in Business (TWIB), it is also a programme forming part of assistance of the Department of Trade and Industry (the DTI). This is a national programme that facilitates access to science and technology for business women. It was introduced in order to accelerate business growth through partnerships, education, training and mentoring. The TWIB was established with the objective of moving women in business from the side-lines to the mainstream of the economy by making use of technology (Department of Trade and Industry, 2011).

TWIB is searching for empowering South African business women as they have the potential to nurture businesses to greater heights. TWIB also assume that women entrepreneurs deserve respect for their achievements. Moreover they should be assisted with new technology and new methods of operations to improve production. From the time it was introduced, TWIB has given hundreds of women the opportunity to apply technology to support and grow their businesses and explore fully the potential of their individual enterprises (Department of Trade and Industry, 2011).

\subsubsection{Isivande Women's Fund}

Isivande Women's Fund (IWF) was launched by the Department of Trade As well as Industry and Old Mutual. It was founded with the aim of providing small, women-owned businesses with affordable, usable and responsive financial solutions.

The IWF targets black women in small businesses as well as female entrepreneurs who are running their own enterprises. It specialises in debt financing, as well as the offering loans ranging from R30 000 to R2-million. For a person to qualify for funding, it is stipulated that the business is supposed to be $60 \%$ female-owned and have at least a two-year track record of business activity and present a sustainable business plan (New Business Development, 2008).

It also focuses on professional women with feasible business ideas, high potential survivalists, micro enterprises and co-operatives depending on the need of the enterprise. The Funding assists with start-up financing, business expansions, business rehabilitations and venture turnaround, franchises and bridging finance.

The IWF was formed as a result of research that confirmed that limited access to finance for women hinders the founding, development, sustainability and profitability of women's enterprises. IWF is an effort by government to improve women's access to formal finance in the absence of personal savings and gender bias in existing lending institutions. The Fund improves and expands access to finance to women entrepreneurs by lending and investing in women enterprises and thus generating income that could improve their living standards.

\subsubsection{Bavumile}

Upgrading the basic skills of women with home-based enterprises to produce quality, commercially-viable, crafts and other culturally-based products, is the Bavumile Skills Development Initiative's primary objective (BSDI). According to Department of Trade and industry (DTI) (2010) South African women are gifted in both designing and crafting fashionable products that reflect the country's cultures and heritage for both the local and international markets. However, one of their greatest challenges is to produce high quality products that will sell well anywhere in the world. With the emphasis on both skills development and empowering women economically in mind, Bavumile is an initiative of the (DTI) which seeks to:

- Find and recruit women who are currently involved in the creative, clothing and textile industries, with skills in embroidery, weaving, netting, sewing and beading;

- Provide specialist skills training and help them to establish their own enterprises or co-operatives; and

- Provide additional training in packaging, customer service, basic bookkeeping and establishing an enterprise or cooperative.

\subsection{Other support stratigies}

Apart from the above support programmes offered by the DTI, there are other institutions that offer support to women entrepreneurs which are discussed below:

\subsubsection{Khula Enterprise Finance Limited}

Khula Enterprise was formed by the government with the mission to ensure improved availability of loans and equity 
capital to SMMEs. A subordinate of Khula, namely Khula Institutional Services, recognized particular financing problems among rural women. Upon the identification of these problems they subsequently launched the Khula Start and Micro Start programmes to promote delivery of microcredit to rural women and the poor. These loans range from R300 to R3 500 , and $70 \%$ of the loans were to go to women (Khula Enterprise Finance Limited, 1999). Khula Capacity Building is also involved in the training of both male and female retail financial intermediaries.

\subsubsection{Ntsika Enterprise Promotion Agency}

This agency was introduced to assist all entrepreneurs on services such as entrepreneurial and business training, business network and information research. Local business service centres were also opened to provide counseling and basic training services as well as business development services. Ntsika has pledged its extraordinary support for women's enterprise initiatives (Ntsika Enterprise Promotion Agency, 1999).

\section{Concluding Remarks}

This paper engrossed on the overview of women entrepreneurs in South Africa. An extensive literature review of the contributions and significance of women entrepreneurs to the economy of South Africa was done. Support strategies for women entrepreneurs were discussed and it was found that the Government has a lot of initiatives targeting the success of women entrepreneurs. From the review of the literature it is noticed that women entrepreneurs are contributing significantly to the economy of the country in terms alleviating poverty, job creation and even to the gross domestic product. It is recommended that the government should put an effort to make all these support initiatives made known to all women entrepreneurs in the country.

\section{References}

Africa Awards for Entrepreneurship. (2011) South African Women Entrepreneurs Are Not Encouraged By Government To Make Money Online. [Online]. Available From: Http://Satrader.Com/Entrepreneurs/South-African-Entrepreneurs/Can-Sa-WomenEntrepreneurs-Make-Money-Online/ (November 28, 2013).

Department of Trade and Industry. (2006) Draft Strategic Framework Of Gender and Women's Economic Empowerment [Online]. Available From: Http://Www.Dti.Org.Za (November 28, 2013).

Department of Trade and Industry. (2011) Deputy Minister Thabethe Calls For Business Women To Enter For The 2011 Technology For Women In Business (TWIB) Awards.[Online]. Available From: Http://Www.Info.Gov.Za/Speech/Dynamicaction?Pageid $=461 \&$ Sid=20228\&Tid=38047 (December 15, 2013).

Khula Enterprise Finance Limited. (1999) Http:// Www.Khula.Org.Za (December 15, 2013)

Maas, G. and Herrington, M. (2006) Global Entrepeneurship Monitor: South African Executive Report. Graduate School Of Business. Cape Town: University Of Cape Town.

Nieman, G.H \& Nieuwenhuizen, C. (2003) Entrepreneurship. A South African Perspective. 2nd Ed. Pretoria: Van Schaik.

Nieman,G., \& Nieuwenhuis,C. (2009) Entrepreneurship: A South African Perspective. Pretoria: Van Schaiks.

Nieman,G.H A \& Bennet, A. (2002) Business Management: A Value Chain Approach. Pretoria: Van Schaik.

Nieuwenhuizen, C. (2003) The Nature And Development Of Entrepreneurship. In G. Nieman \& J. Houg (Eds.), Entrepreneurship: A South African Perspective. Pretoria: Van Schaik.

Ntsika Enterprise Promotion Agency. (1999) Http://Www.Ntsika.Org.Za (December 11,2013).

Ntsika Enterprise Promotion Agency. (2000) State Of Small Business In South Africa Policy And Research Division. Pretoria.

South African Government Information. (2011) Keynote Address By President Jacob Zuma On National Women's Day, Peter Mokaba Stadium, Limpopo. [Online]. Available From: Http://Www.Info.Gov.Za/Speech (December 13, 2013).

South Africa Info. 2004. Women Entrepreneurs' Network. [Online]. Available From: Http://Www.Southafrica.Info/Doing_Business/Trends Momen/Sawen.Htm (December 13, 2013).

Thurik, R, A \& Wennekers, S. (2001) A Note On Entrepreneurship, Small Business And Economic Growth. Rotterdam: Erasmus Research Institute Of Management Report Series.

Van Aardt, I. Van Aardt, C. Bezuidenhout, S. \& Mumba, M. (2008) Entrepreneurship And New Venture Management (3rd Ed). Cape Town: Oxford University Press.

White, M.M., Jones,J.M., Riley, K. \& Fernandez.R. (2009) Women, Family And The Rural Economy. Fullbright- Hays Group Project Abroad.

Women in Africa Doing Business. (2008) Case studies of women entrepreneurs across Africa who have overcome legal and regulatory obstacles to create new business opportunities. [online]. Available from: http://www.doingbusiness.org/ /media/FPDKM/Doing \%20Business/Documents/Special-Reports/Women-in-Africa.pdf (December 13, 2013), 